\title{
Agronomic practices and adaptive strategies of the farmers to climate change in central Pakhtunkhwa, Pakistan
}

\author{
Shakeel Ahmad ${ }^{1 *}$, Muhammad Israr ${ }^{2}$ and Muneeb Ur Rehman ${ }^{3}$
}

1. Department of Environmental Sciences, COMSATS Institute of Information Technology, 22060 AbbottabadPakistan

2. Department of Rural Development, Faculty of Rural Social Sciences AMKC, Mardan, The University of Agriculture Peshawar-Pakistan

3. Institute of Development Studies, Faculty of Rural Social Sciences, The University of Agriculture Peshawar-

Pakistan

*Corresponding author's email: shakeel.env@gmail.com

Citation

Shakeel Ahmad, Muhammad Israr and Muneeb Ur Rehman Agronomic practices and adaptive strategies of the farmers to climate change in central Pakhtunkhwa, Pakistan. Pure and Applied Biology. Vol. 6, Issue 4, pp11321150. http://dx.doi.org/10.19045/bspab.2017.600122

Received: 02/04/2017 Revised: 27/08/2017

Accepted: 06/09/2017

Online First: $14 / 09 / 2017$

\section{Abstract}

Individuals' observation on environmental change perceived as a basic commitment to agrarian research for the future sustainability of agriculture. This research gives a based strategy to create a foundation for the practices and ecological databases of agronomic practices of Mardan district in Khyber Pakhtunkhwa-Pakistan by choosing a sample size of 138 haphazardly farmers family units. Data was gathered in regards to the agronomic practices and climate change by interview methods. Findings revealed that in the region main crops were wheat, maize, rice and sugarcane and majority facing the climate change. Because of the climatic changes the production of various crops was altogether diminished as significant value of chi-square (14.64). Over populace $(64 \%)$ and deforestation (32\%) are the drivers of climate change in the area. Majority (76\%) feel the change in the rain pattern and the temperature is more when contrasted with past 10 years. Ordinary, zero and hand burrowing cultivation practices are utilized for field operation and the most regular techniques for seeds sowing and fertilizer was broadcasting. The principle versatile and mitigative measure of the ranchers were changed in planting time, best decision of yield, decision of seed change and recurrence, change in manure application and timing. Destitution, ignorance, the absence of intrigue and advanced adjustment and relief strategies are the elements dependable to defeat the climate change. The surges circumstances and land degradation are the issues because of climatic changes. The study concludes that environmental changes unfavorable influenced all spears of activities of the agriculturists which have to affect economy of the country.

Keywords: Adaptive practices; Agronomic interventions; Climate change; Food crops

Introduction

Climate change with associated extreme weather events results agriculture is one of the most vulnerable sectors [1]. The changing climatic scenario and its impact on various sectors of the economy have 
emerged as one of the greatest challenges before the scientists and policy makers all over the world in present century [2]. These negative consequences from climate change pose a direct threat to the success of agriculture and farmers welfare at local and global scales. The farmer's welfare depends on the nature and severity of the climate signal, non-climate related stressors and the ability of farmers to cope in any given technological and regulatory environment [3]. Global climate change is happening throughout the world and impacting all kind of ecosystem services to mankind [4]. There are a few regions in the world where climate change might be rapid and even very low where the penalty of climate change are likely to be as severe for biodiversity, ecosystems services and human well-being [5]. Higher temperature and changing precipitation levels caused by climate change may decline crop yields in many countries in coming decades [6]. Climate variability together with extreme climatic events threatens natural and human systems across the world [7]. Climate changes are likely to reduce food production and potentially exacerbate food insecurity in many parts of the world in the next couple of decades [8, 9]. The variability of available climate and agro-meteorological disaster risks during the entire growing season in sensitive to food and cash cropping areas [10].

Farmer's perception on climate change can be recognized as a critical contribution to environmental and health problems, agricultural production and possible solutions [11, 12]. Farmers who are engaged in agriculture system do experience impact of climate changes on production and yield of crops and have knowledge about climate change are more likely to believe in the potential of future risks, associated with high-end climate changes and agronomic practices $[13,14]$. A better understanding of the farmers to climate change with their ongoing adaptation measures is needed to expertise through development of policies and strategies for better production and yield from agricultural sector [15, 16]. The researchers are testing new approaches to cope with the climate change based on their traditional knowledge and learning experiences. They are more concerned with adaptation to climate change rather than the nature and degree of these changes. Farming communities observed climatic conditions as embedded in socio-ecological system and indigenous knowledge would indeed supplement rather than replace scientific knowledge about climate change [17, 18]. The exchangeability method identified that climate change beliefs and past experiences with crop losses were critical to farmers' agricultural risk perceptions [14]. Farmers' perceptions of climate change risk significantly affect agricultural adaptation [19].

Adaptation to climate change is recognized as the most pressing research question in the most recent and comprehensive overview on the social and economic impact of climate changes [20]. The importance of adaptation has also been recently recognized as the missing link to bridge short-run impacts to long-run interpolation [21]. It seems to be the most efficient and effective mean to the farmers to cope with the impacts of climate changes $[22,23]$. It has the potential to reduce adverse impacts of climate change and to enhance beneficial impacts [24]. Also it has been found to constitute a key strategy to cope with the negative effects of climate changes [25]. But due to lack of communication between extension workers and development specialist in rural areas, their learning is not being disseminated to others who could be benefited in other parts having similar geographic and ecological conditions through formal institutional and governmental channel [26]. Adaptation has 
been quite effective in increasing food productivity [27], as it improves crop yields by $15-18 \%$ of the current yields, but the effectiveness of adaptation has varied significantly across different regions of the world [7].

Several global as well as regional studies [28-32] pointed that the productivity of food crops, livestock and fish may decline even in the short-term with significant effects later in the century, if corrective actions are not taken now, to improve the adaptive capacity. This will be done by several technological interventions and policy measures to bring about this transformation. Changes in agronomic practices, adoption of the new technologies and the use of relevant information at the farm level are the key components in improving the adaptation of agriculture to climate change and many of these interventions have been successful in increasing production, income and building resilience among farming communities in many areas of the world [1].

There are relatively few studies in the literature showing work on prioritizing climate-smart agriculture interventions in the farmer's perspectives for the adoption $[33,34]$. Several recent studies [35-37] have shown the application of production functions, crop simulation models, and field survey to generate such data for a regional food security planning are too much important for future policy formulation.

There is a need to explicitly assess the impacts of climate change with agronomic scenarios representative of local farming practices [38]. Several tools are now available that are able to provide quick estimates of farmers perspectives of various agronomic interventions [39]. This paper objective is to provide a based methodology to generate a background for the agronomic practices and environmental databases of agronomic adaptive/ mitigative interventions within the farmer's perspectives at regional level.

\section{Materials and methods}

Mardan District of central Khyber Pakhtunkhwa-Pakistan was the sample area for this research (Figure 1). It is one of the best agriculture areas due to its suitability for cultivation of food and cash crops. Fruits and vegetables are also grown and it includes oranges, apples, peachs, plums, apricots, rare mango and pears. District Mardan was divided into five clusters i.e. north, south, west, east and central. Among the clusters, proportionate stratified cluster, random sampling was applied and from the four union council's viz. Garo Shah, Machai, Shahbaz Gari and Manga were selected purposively because of growing of a particular food crops.

Appropriate sample size for a population based survey is determined by the factors i.e. variable of interest, estimated prevalence, confidence level and acceptable margin of error [40]. This study was based on simple random sample; therefore, the sample size was calculated by using the formula. $n=t^{2} \times p(1-p) / m^{2}$ Where, $n=$ Sample size required, $\mathrm{t}=$ Confidence level, $\mathrm{p}=$ estimated prevalence i.e. climate change effected household, $\mathrm{m}=$ marginal error at $5 \%$.

By taking the standard value (1.96) at $95 \%$ confidence interval, marginal error standard value i.e. 0.05 and estimated roughly that $90 \%$ (0.9) of the farming household were affected by the climate change, by putting all these values in the aforementioned formula the required sample size were 138 Primary data were collected by face to face interview method through a well-designed pre-tested questionnaire from the farmer households regarding their agronomic practices, adaptive/ mitigative measures and the climate change phenomena. The unit of analysis for this study was the heads of 
household involved in the food crops farming in the selected area.

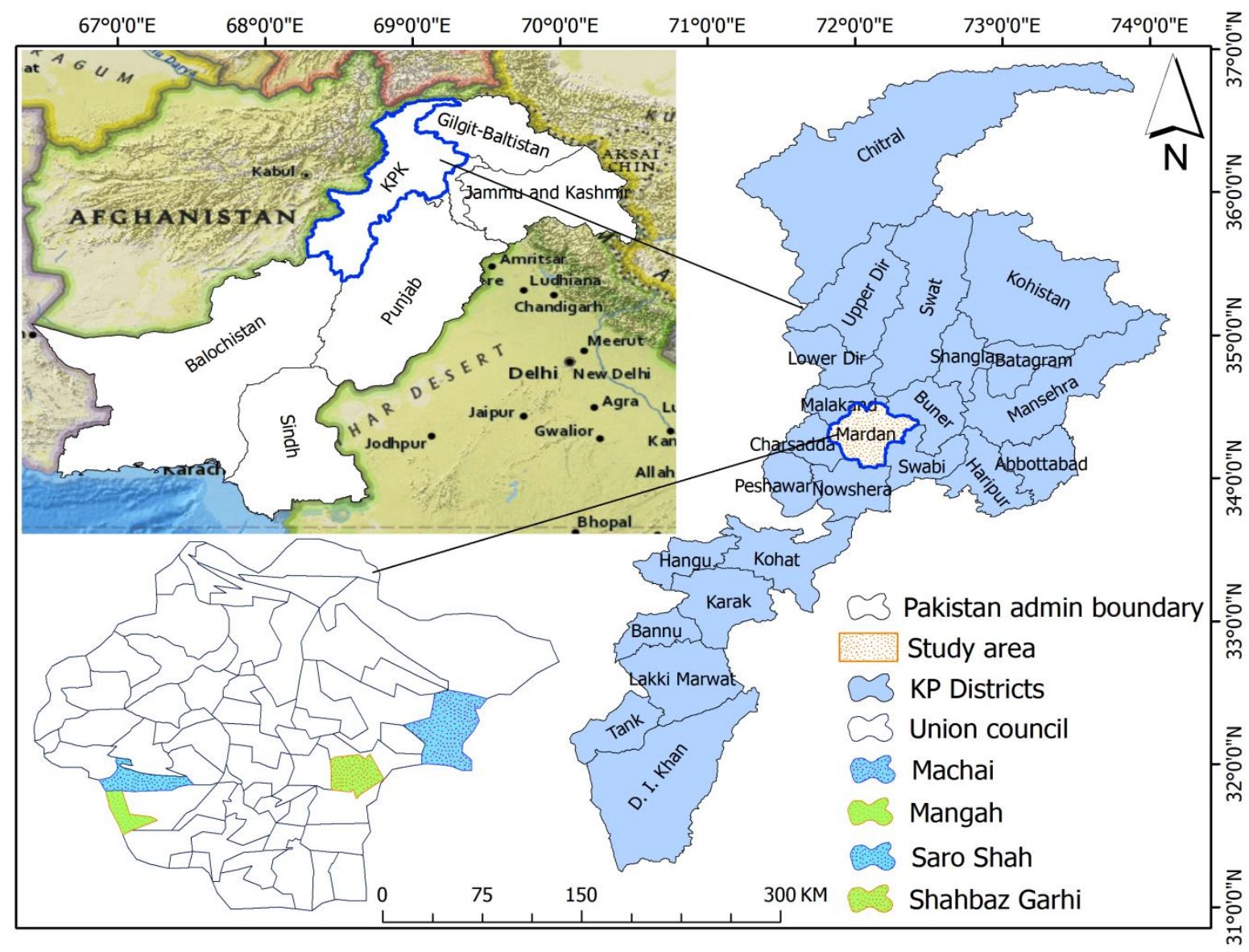

Figure 1. Map of Pakistan, Khyber Pakhtunkhwa and selected area of research

Source: Adopted from Google map and own collaboration

\section{Agronomic practices}

Agronomic practices are steps taken by the farmers at the farm management level to improve soil quality, enhance water use, manage crop residue and improve the environment through better fertilizer management. Climate change has adversely affected farming household because agriculture is the most vulnerable sector to climate change. Different agronomic practices are done to increase productivity of crops as a result of new technological explorations, new agronomic practices are invented for increased crop production i.e. (i) Replacement of conventional tillage (ii) advanced methods to use the fertilizers (iii) sustainable new irrigation methods (iv) planting methods i.e. broadcast, split method, etc. are replaced by different modern machines.

1) Climate change effect tillage system in different ways, farmers needs to use modern technology for tillage in their fields.

2) Organic farming needs to be preferred wherever possible and inorganic fertilizer used needs appropriate methods and timing.

3) Climate change severely effect irrigation water for crops as canal water in majority cases are polluted through different anthropogenic activities which affects crop production.

4) By broadcast method of cultivation many seeds and fertilizers become throw away, 
and as a result yields low crop productivity.

\section{Adaptation practices}

Adaptation is the process made up of actions throughout society, individuals, groups and governments [41]. Adaptation strategies of the farmers includes sowing of early maturity crop verities, flooding experience, perceived change in rain timings, altering the time and location of cropping activities, diversifying of income through integration with other farming activities and rearing livestock. The reasons for taking these strategies in the research are as under;

1) Due to severe floods, droughts, hurricanes and rain storms, the crops ready to harvest are destroyed, so as an adaptive strategy the farmers need to sow alternative crops to overcome the phenomenon.

2) Farmers need to sow the type of seeds that have the quality to overcome the flooding experience.

3) As the rain timings changed with climate change the farmer's needs to adopt change in sowing timings for crops especially in rain fed areas.

4) Farmers need to alter the time and location of sowing and harvesting crops.

5) Farmers need to invest their assets in different sector as income diversification strategy.

6) Rearing livestock is another source of income for the farming household which would help them in fulfilling their needs accordingly.

\section{Mitigation strategies}

Mitigation is the efforts to reduce/prevent emissions of greenhouse gases by means of new technology. Mitigative measures taken by the farmers were crop insurance, mixed cropping, change in planting dates, varieties having pest/disease tolerance, early maturity verities of crops and varieties having drought tolerance capacities. The following are the reasons due to which the above mitigative measures are selected.

1) To overcome the losses during any bad climatic situation crop insurance needs to be done by famers in order to keep their income safe.

2) Farmers need to have more than one variety in their field to overcome different drastic climatic situations.

3) Sowing and harvesting timings needs to be changed according to weather situations.

4) Farmers need to cultivate those varieties that have the capability to tolerate pests and different ecological problems.

5) Early maturity verities need to be sown to overcome climate change problems.

6) Varieties which need less irrigation need to be grown in order to get good results and overcome the problem of water scarcity.

Primary data on all aspects of the above agronomic practices and adaptive/ mitigative measures were selected and were tested through relevant test for the assumptions of normality and randomness of data. After fulfilling the assumptions different descriptive statistics such as mean, standard deviation, chi-square test, variance and frequency distribution were used for its analysis and were interpreted below.

\section{Results and discussion Agronomic practices 1. Crops grown}

Climate changes affect cropping pattern and production directly by rise in temperature, changes in precipitation and moisture availability. Cereal crop production considered highly sensitive to temperature rises and therefore, food insecurity is expected to increase in a couple of upcoming decades if the clime change process continue. The respondents grow wheat, maize, rice, sorghum, and sugarcane. More than half of the respondents mentioned for the growing of wheat in the area, while a 
small percentage of respondents reported for the rice growing (Table 1). This is due to the land unsuitability for the growing of rice.
The results of the Chi-square pointed that there is no association in the respondents opinion about the sowing of different crops.

Table 1. Distribution of respondents according to crops grown

\begin{tabular}{|l|c|c|c|c|c|c|c|c|c|}
\hline \multicolumn{10}{|c|}{ Crops grown in the area } \\
\hline UCs Name & Wheat & Maize & Rice & Sorghum & Sugarcane & Total & Mean & Std.Dev. & Var. \\
\hline Garo shah & $39(30)$ & $39(30)$ & $19(15)$ & $11(9)$ & $21(16)$ & 129 & 0.57 & 0.49 & 0.24 \\
\hline Machai & $19(26)$ & $18(24)$ & $15(20)$ & $14(19)$ & $8(11)$ & 74 & 0.72 & 0.45 & 0.20 \\
\hline Shahbaz Gari & $49(32)$ & $49(32)$ & $23(15)$ & $20(13)$ & $13(8)$ & 154 & 0.53 & 0.50 & 0.25 \\
\hline Manga & $26(33)$ & $24(30)$ & $12(15)$ & $11(14)$ & $06(8)$ & 79 & 0.50 & 0.50 & 0.25 \\
\hline Total & $133(30)$ & $130(30)$ & $69(16)$ & $56(13)$ & $48(11)$ & $436^{*}$ & 0.58 & 0.48 & 0.23 \\
\hline \multicolumn{8}{|c|}{ Chi-square=11.98, p-value=0.4469, not significant at p<0.05 } \\
\hline
\end{tabular}

* The total exceed because of the multiple crops sowed by the respondents in the fields

Source: Field Survey, 2016

\section{Climate change knowledge}

Perceptions are a range of viewpoint, judgments and attitudes [42]. The developing countries farmers face the variability and climate change process. Farmers' information and experience to climate change have been pretentious by numbers of factors i.e. education, interest size of land and age of the farmers. This research indicates that understanding is significant factor that shapes farmer perceptions on climate change and variability (Table 2) and it is clear that majority $(71 \%)$ of the respondents having the knowledge of climate change and experiences this phenomenon by one way or the other at their fields. No significant association was observed in the farmer's perceptions in the union councils about the knowledge of climate change.

Table 2. Distribution of respondents on knowledge of climate change

\begin{tabular}{|l|c|c|c|c|c|c|}
\hline \multicolumn{7}{|c|}{ Climate change phenomena } \\
\hline UCs Name & Having knowledge & Having no knowledge & Total & Mean & Std. Dev. & Var. \\
\hline Garo shah & $32(82)$ & $7(20)$ & 39 & 0.5 & 0.50 & 0.25 \\
\hline Machai & $17(81)$ & $4(19)$ & 21 & 0.5 & 0.506 & 0.256 \\
\hline Shahbaz Gari & $35(67)$ & $17(33)$ & 52 & 0.5 & 0.50 & 0.252 \\
\hline Manga & $14(54)$ & $12(46)$ & 26 & 0.5 & 0.50 & 0.254 \\
\hline Total & $98(71)$ & $40(29)$ & 138 & 0.5 & 0.504 & 0.254 \\
\hline \multicolumn{7}{|l|}{ Chi-square $=7.386$, p-value $=0.0606$, not significant at $\mathrm{p}<0.05$} \\
\hline
\end{tabular}

Source: Field Survey, 2016

\section{Climate change effects on crops and weather}

Climate change also affects the production of crops at the field and also the monsoon season. Duration of seasons has changed, average temperature both in summer and winter has increased and rainfall received in diverse regions has declined considerably and became more inconsistent. The temperature increases in Pakistan and become higher than the global average resulting in reduced national agricultural productivity. The minimum and maximum temperatures have increased both in summer and winter seasons almost throughout Pakistan [43]. Climate change results in rapid melting of glaciers, which have serious repercussions for river flows in Pakistan. Due to more water availability causes floods and severe droughts afterwards [44]. On average agriculture sector of Pakistan would lose 2-16 billion dollars per annum due to 
change in climate by the end of $21^{\text {st }}$ century [45]. This was reported by the majority of the respondents that due to climate changes the production of different crops was significantly decreased as conformed by the value of chi-square (Table 3). Also some of the respondents reported that due to climate change process the monsoon timings are increased from the normal and thus affected the agriculture sector in the area.

Table 3. Distribution of respondents on effects of climate change crop production/weather conditions

\begin{tabular}{|l|c|c|c|c|c|c|c|c|}
\hline UCs Name & $\begin{array}{l}\text { Increase in } \\
\text { production }\end{array}$ & $\begin{array}{l}\text { Decrease in } \\
\text { production }\end{array}$ & $\begin{array}{l}\text { Increase in } \\
\text { monsoon }\end{array}$ & $\begin{array}{l}\text { Decrease in } \\
\text { monsoon }\end{array}$ & Total & Mean & $\begin{array}{l}\text { Std. } \\
\text { Dev. }\end{array}$ & Var. \\
\hline Garo shah & $10(26)$ & $22(56)$ & $5(13)$ & $2(5)$ & 39 & 0.19 & 0.40 & 0.16 \\
\hline Machai & $2(9)$ & $14(67)$ & $5(24)$ & $0(00)$ & 21 & 0.22 & 0.41 & 0.17 \\
\hline Shahbaz Gari & $3(6)$ & $29(55)$ & $16(31)$ & $4(8)$ & 52 & 0.16 & 0.37 & 0.13 \\
\hline Manga & $3(12)$ & $12(46)$ & $10(38)$ & $1(4)$ & 26 & 0.17 & 0.38 & 0.14 \\
\hline Total & $18(13)$ & $77(56)$ & $36(26)$ & $7(5)$ & 138 & 0.18 & 0.39 & 0.15 \\
\hline \multicolumn{7}{|l|}{ Chi-square $=14.46, p$-value $=0.1068$, not significant at $p<0.05$} \\
\hline
\end{tabular}

Source: Field Survey, 2016

Adaptive and mitigative measures

\section{Climate change causes}

Climate change is a diverse phenomenon to overcome. Human population is getting higher and higher in several decades and is growing with the sky rocketing speeds. Different hazardous gases and emissions are added to environment every day by the humans through different activities. Areas of high population expansion and high susceptibility to climate change impact lie on top. Evidence suggests that the poorest countries and poorest groups within a population are most vulnerable to climaterelated hazards such as floods, droughts, and landslides [46]. This study finds that overpopulation is the main cause of climate change as reported by the majority (64\%) of the respondents as because the increasing temperature is all about the human activities. The growth rate of Pakistan is $1.49 \%$ which has a direct link with the climate change process and its effect on the agriculture sector in the country. The second important cause reported by the respondents was deforestation and it may also link with population increase. The deforestation rate in Pakistan is the highest in Asia, about 2.1 percent, and only 2.5 percent of the country's total area is forest cover. So, it was clear from the data that over population and deforestation are the two main causes of climate change in the area as show in Table 4.

Table 4. Distribution of respondent's on causes of climate change

\begin{tabular}{|l|c|c|c|c|c|c|c|}
\hline \multicolumn{7}{|c|}{ Causes of climate change } \\
\hline UCs Name & Deforestation & $\begin{array}{l}\text { Over } \\
\text { population }\end{array}$ & Any other & Total & Mean & Std. Dev. & Var. \\
\hline Garo shah & $6(15)$ & $32(82)$ & $1(3)$ & 39 & 0.31 & 0.46 & 0.21 \\
\hline Machai & $8(38)$ & $12(57)$ & $1(5)$ & 21 & 0.40 & 0.49 & 0.24 \\
\hline Shahbaz Gari & $20(38)$ & $30(58)$ & $2(4)$ & 52 & 0.32 & 0.46 & 0.21 \\
\hline Manga & $10(38)$ & $14(54)$ & $2(8)$ & 26 & 0.30 & 0.46 & 0.21 \\
\hline Total & $44(32)$ & $88(64)$ & $6(4)$ & 138 & 0.33 & 0.47 & 0.22 \\
\hline \multicolumn{7}{|l|}{ Chi-square=8.526, p-value=0.202, not significant at p<0.05 } \\
\hline
\end{tabular}

Source: Field Survey, 2016 


\section{Climate change and raining level}

Climate change adversely affects the rain pattern in the developing countries because of the different activities done by human beings. In third world countries, there is lack of basic infrastructure facilities which can overcome the disastrous situation such as floods and rains etc. Deforestation is another big issue in the changed rain pattern. People burn wood as a fuel which causes the environmental damage because forests control the atmosphere. Due to which

Table 5. Distribution of respondents on level of changes felt in rain

\begin{tabular}{|l|c|l|l|l|r|r|l|}
\hline \multicolumn{7}{|c|}{ Change in raining level } \\
\hline UCs Name & Less & More & Same & Total & Mean & Std. Dev. & Var. \\
\hline Garo shah & $1(3)$ & $27(69)$ & $11(28)$ & 39 & 0.32 & 0.47 & 0.22 \\
\hline Machai & $3(14)$ & $18(86)$ & $0(00)$ & 21 & 0.33 & 0.47 & 0.22 \\
\hline Shahbaz Gari & $19(36)$ & $29(56)$ & $4(8)$ & 52 & 0.33 & 0.47 & 0.22 \\
\hline Manga & $7(27)$ & $18(69)$ & $1(4)$ & 26 & 0.33 & 0.47 & 0.22 \\
\hline Total & $30(22)$ & $92(67)$ & $16(11)$ & 138 & 0.33 & 0.47 & 0.22 \\
\hline
\end{tabular}

Source: Field Survey, 2016

\section{Climate change effect on farmers}

Climate change badly affects agriculture sector because it is the most vulnerable sector to it as it directly dependent on the external environment. Different activities affected in different ways i.e. farmers cultivate crops in fields which are affected by rains, floods, droughts and storms etc. and in result farmers get no reward. It also effects livestock by attacking through different diseases coupled pests attack on fodder. Crops production is one of the main sectors of agriculture affected by climate

Table 6. Distribution of respondents on effects of climate change on farmers

\begin{tabular}{|l|c|c|c|c|c|c|c|c|}
\hline \multicolumn{1}{|c|}{ Effects observed due to climate change } \\
\hline UCs Name & $\begin{array}{l}\text { Cultivation } \\
\text { effected }\end{array}$ & $\begin{array}{l}\text { Reduced } \\
\text { production }\end{array}$ & $\begin{array}{l}\text { Livestock } \\
\text { effected }\end{array}$ & Other & Total & Mean & $\begin{array}{l}\text { Std. } \\
\text { Dev. }\end{array}$ & Var. \\
\hline Garo shah & $15(32)$ & $26(56)$ & $4(8)$ & $2(4)$ & 47 & 0.30 & 0.46 & 0.21 \\
\hline Machai & $14(48)$ & $13(45)$ & $2(7)$ & $0(00)$ & 29 & 0.33 & 0.47 & 0.22 \\
\hline Shahbaz Gari & $19(29)$ & $43(65)$ & $4(6)$ & $0(00)$ & 66 & 0.33 & 0.47 & 0.22 \\
\hline Manga & $9(30)$ & $19(63)$ & $2(7)$ & $0(00)$ & 30 & 0.27 & 0.44 & 0.20 \\
\hline Total & $57(33)$ & $101(59)$ & $12(7)$ & $2(1)$ & $172 *$ & 0.31 & 0.46 & 0.21 \\
\hline \multicolumn{7}{|c|}{ Chi-square $=9.6734, p$-value $=0.3776$, not significant at $\mathrm{p}<0.05$} \\
\hline
\end{tabular}

* The total exceed because of the multiple responses. Source: Field Survey, 2016 


\section{Climate change problems}

The change in Climate poses unprecedented challenges to Pakistan agriculture because of the sensitivity of agricultural productivity and dependence on open climate. The study shows the respondent's opinion for problems faced due to worse climate in the area. It was evident from findings that respondents indentified three problems they are facing due to worse climate in the area. This includes storms and floods situations, degradation of the land and different crop diseases (Table 7). These findings was in line with the findings of [47] pointed that pests and diseases offer particular challenges to climate change effects due to the strong temporal and spatial correlation produced by their spread. Also study of [48] confirmed that extreme precipitation damaging crops due to physically injured plant parts, inject excessive water in the root zone, result in physical damage if high winds accompany rainstorms coupled by the increase in some bacterial and fungal diseases. Further this study confirms that higher temperatures results evaporative losses from land and water surfaces coupled by transpiration losses from non-crop land cover and thus lead to the degradation of land quality with the passage of time.

Table 7. Distribution of respondents on problems resulted from climate change

\begin{tabular}{|l|c|l|c|c|c|c|c|}
\hline \multicolumn{7}{|c|}{ Problems observed due to climate change } \\
\hline UCs Name & $\begin{array}{l}\text { Storms } \\
\text { and Flood }\end{array}$ & $\begin{array}{l}\text { Land } \\
\text { degraded }\end{array}$ & $\begin{array}{l}\text { Crops } \\
\text { diseases }\end{array}$ & Total & Mean & Std. Dev. & Var. \\
\hline Garo shah & $24(47)$ & $18(35)$ & $9(18)$ & 51 & 0.43 & 0.49 & 0.24 \\
\hline Machai & $20(64)$ & $3(10)$ & $8(26)$ & 31 & 0.47 & 0.50 & 0.25 \\
\hline Shahbaz Gari & $40(63)$ & $15(23)$ & $9(14)$ & 64 & 0.42 & 0.49 & 0.24 \\
\hline Manga & $20(57)$ & $6(17)$ & $9(26)$ & 35 & 0.43 & 0.49 & 0.24 \\
\hline Total & $104(58)$ & $42(23)$ & $35(19)$ & $181 *$ & 0.44 & 0.49 & 0.24 \\
\hline
\end{tabular}

* The total exceed because of the multiple responses

Source: Field Survey, 2016

\section{Climate change and temperature level}

Development and growth of crop is mainly a function of temperature, although weather and climate had never been constant and they had always experienced changes either positive or negative but recent atmospheric warming was unprecedented and increasing global warming trend started in 1940s after industrial revolution and it had no end till now [49]. In this regards the farmers perceptions were determined by asking them about the temperature situation during the last five years. The data in Table 8 shows the results of respondent's opinion for comparing temperature with the previous five years in the study area. The findings revealed that the temperature increased (76\%) according to the view of the respondents and less variation were noted among the union councils. This implies that the farmers were aware about the rise in the temperature during the last five years. 
Table 8. Distribution of respondents on changes in temperature during last five years

\begin{tabular}{|l|c|c|c|c|c|c|c|}
\hline \multicolumn{7}{|c|}{ Change in temperature } \\
\hline UCs Name & Increased & Decrease & Same as previous & Total & Mean & Std. Dev. & Var. \\
\hline Garo shah & $32(82)$ & $5(13)$ & $2(5)$ & 39 & 0.08 & 0.28 & 0.08 \\
\hline Machai & $14(67)$ & $5(24)$ & $2(9)$ & 21 & 0.16 & 0.37 & 0.14 \\
\hline Shahbaz Gari & $39(75)$ & $4(8)$ & $9(17)$ & 52 & 0.11 & 0.31 & 0.10 \\
\hline Manga & $20(77)$ & $2(8)$ & $4(15)$ & 26 & 0.15 & 0.36 & 0.12 \\
\hline Total & $105(76)$ & $16(12)$ & $17(12)$ & 138 & 0.12 & 0.33 & 0.11 \\
\hline \multicolumn{7}{|c|}{ Chi-square $=7.234, \mathrm{p}$-value $=0.2997$, not significant at $\mathrm{p}<0.05$} \\
\hline
\end{tabular}

Source: Field Survey, 2016

\section{Climate change effects on livestock}

According to the findings of [50] that climate changes not only affect the crops and agriculture production, but also having adverse effect on other sectors of the agriculture. As in pastoral and agro-pastoral systems, livestock is a key asset for poor people, fulfilling multiple economic, social and risk management functions and with the passage of time the society and farmers developed agriculture practices that were based on their understanding of weather and climate patterns, includes the appropriate time of the year to move livestock from summer to winter grazing areas and also to best plan for the fodder and feed supply during the scarcity period. Such practices have been used over the centuries, and continue to be used right up to the present day. They were frustrated by the variability of the seasons and even the day-to-day weather, and as a coping strategy developed folktales and rules of thumb for the weather and climate patterns. The data in Table 9 shows the results of respondent's opinion for effects on the livestock after reduction of production of crops and grasses due to climate change in the study area and majority of the respondents reported that the numbers of livestock are decreased as a result of the less feed availability for feeding the livestock. Also more variation was noted among the opinion of the respondents in the union councils.

Table 9. Distribution of respondents on climate change effects on livestock level

\begin{tabular}{|l|c|c|c|c|c|c|c|}
\hline \multicolumn{7}{|c|}{ Climate changes effect on livestock } \\
\hline UCs Name & $\begin{array}{l}\text { Decrease in } \\
\text { number }\end{array}$ & $\begin{array}{l}\text { Increase in } \\
\text { number }\end{array}$ & $\begin{array}{l}\text { Same as } \\
\text { previous }\end{array}$ & Total & Mean & $\begin{array}{l}\text { Std. } \\
\text { Dev. }\end{array}$ & Var. \\
\hline Garo shah & $21(54)$ & $2(5)$ & $16(41)$ & 39 & 0.41 & 0.49 & 0.24 \\
\hline Machai & $16(76)$ & $0(0)$ & $5(24)$ & 21 & 0.27 & 0.46 & 0.21 \\
\hline Shahbaz Gari & $39(75)$ & $0(0)$ & $13(25)$ & 52 & 0.26 & 0.44 & 0.19 \\
\hline Manga & $19(74)$ & $0(0)$ & $7(26)$ & 26 & 0.23 & 0.43 & 0.18 \\
\hline Total & $95(69)$ & $2(1)$ & $41(30)$ & 138 & 0.29 & 0.45 & 0.21 \\
\hline \multicolumn{7}{|c|}{ Chi-square=9.253, p-value=0.1598, not significant at $\mathrm{p}<0.05$} \\
\hline
\end{tabular}

Source: Field Survey, 2016

\section{Climate change affects on farmers livelihoods}

Change in climate has posed a severe hazard to majority of the farmers in the developing countries. As agriculture is an important industry catering for livelihoods for many people in developing countries. Also agriculture is their main source of income and $75 \%$ of the world's poor are living in rural areas and climate change have been far-reaching effect on it because of lack of proper infrastructure and other allied facilities. The date in Table 10 presents the perceptions of respondents regarding the 
effects of climate change on the people. The respondents were of the view that the climate change affected the livelihoods, production of crops and also results the change in profession from agriculture to the non-agriculture. The variation in the perception of the respondents among the union councils was almost the same. This implies that the process of climate change adversely affected all aspects of the farmers in the area and brings the shifting/diversification from one profession to the others, which have impact on the rural economy.

Table 10. Distribution of respondents on effects of climate change on farmers livelihoods

\begin{tabular}{|l|c|l|l|l|l|l|l|}
\hline \multicolumn{2}{|c|}{ Effect of climate change } \\
\hline UCs Name & $\begin{array}{l}\text { Effected } \\
\text { livelihood }\end{array}$ & $\begin{array}{l}\text { Effected } \\
\text { production } \\
\text { of crops }\end{array}$ & $\begin{array}{l}\text { Compelled } \\
\text { to change } \\
\text { occupation }\end{array}$ & Total & Mean & $\begin{array}{l}\text { Std. } \\
\text { Dev. }\end{array}$ & Var. \\
\hline Garo shah & $27(49)$ & $12(41)$ & $16(10)$ & 55 & 0.47 & 0.50 & 0.25 \\
\hline Machai & $15(44)$ & $4(28)$ & $10(8)$ & 29 & 0.48 & 0.50 & 0.25 \\
\hline Shahbaz Gari & $43(48)$ & $16(38)$ & $17(14)$ & 76 & 0.46 & 0.50 & 0.25 \\
\hline Manga & $23(54)$ & $11(42)$ & $9(4)$ & 43 & 0.54 & 0.50 & 0.25 \\
\hline Total & $108(53)$ & $43(21)$ & $52(26)$ & $203^{*}$ & 0.49 & 0.50 & 0.25 \\
\hline \multicolumn{7}{|c|}{ Chi-square=3.3325, p-value=0.766, not significant at p<0.05 } \\
\hline
\end{tabular}

* The total exceed because of the multiple responses

Source: Field Survey, 2016

\section{Climate change and area soil types}

Soils are acknowledged to be in the front line of international environmental change. This requires a better understanding of the role of soils in the climate change to ensure that they continue to provide production for humanity and the natural world [51]. The data in Table 11 shows the results of respondent's distribution about opinion for the type of soil in the study area. It is evident from the data that $74 \%$ of the respondents reported for the clay soil in the area, while $17 \%$ mentioned for the clay loam soil in the area. The literature pointed that the clay soil is badly affected by the changes in the environment as having no resistance to flood and heavy rain. Therefore, the soil of the area is too much sensitive to the process of climate change.

Table 11. Distribution of respondents on the basis of soil types

\begin{tabular}{|l|c|c|c|c|c|c|c|}
\hline \multicolumn{7}{|c|}{ Soil types } \\
\hline UCs Name & Clay & Sandy loam & Clay loam & Total & Mean & Std. Dev. & Var. \\
\hline Garo shah & $34(90)$ & $5(5)$ & $0(00)$ & 39 & 0.30 & 0.46 & 0.21 \\
\hline Machai & $16(83)$ & $0(00)$ & $5(5)$ & 21 & 0.33 & 0.47 & 0.22 \\
\hline Shahbaz Gari & $32(60)$ & $5(10)$ & $15(30)$ & 52 & 0.33 & 0.47 & 0.22 \\
\hline Manga & $20(60)$ & $2(3)$ & $4(37)$ & 26 & 0.27 & 0.44 & 0.20 \\
\hline Total & $102(74)$ & $12(9)$ & $24(17)$ & 138 & 0.31 & 0.46 & 0.21 \\
\hline \multicolumn{7}{|c|}{ Chi-square $=15.986, p$-value $=0.0138$, significant at $\mathrm{p}<0.05$} \\
\hline
\end{tabular}

Source: Field Survey, 2016

\section{Climate change and area tillage system}

Tillage may enhance or retard emissions of greenhouse gases from agriculture, and may help maintain the productive base under the conditions of climate change. Tillage and land management practices clearly influence a whole host of interactions between soil structure and biota, and this in turn 
influences the stability of carbon and nitrogen within the soil matrix [52]. The data in Table 12 shows the perception of the respondents about the opinion for tillage system. Three types i.e. conventional, zero and hand digging tillage system are used in the area for the operation of the field land.
Majority of the respondents reported that they are using conventional tillage system in the area. This implies that this type of tillage system produces more for the farmers and also manages the crop properly. Among the union councils less variation were noted by the descriptive statistics.

Table 12. Distribution of respondents on tillage system use

\begin{tabular}{|l|c|c|c|c|c|c|c|}
\hline \multicolumn{7}{|c|}{ Tillage system } \\
\hline UCs Name & Conventional & Zero & Hand digging & Total & Mean & Std. D. & Var. \\
\hline Garo shah & $32(82)$ & $2(5)$ & $5(13)$ & 39 & 0.30 & 0.46 & 0.21 \\
\hline Machai & $15(71)$ & $1(5)$ & $5(24)$ & 21 & 0.33 & 0.47 & 0.22 \\
\hline Shahbaz Gari & $49(94)$ & $0(00)$ & $3(6)$ & 52 & 0.33 & 0.47 & 0.22 \\
\hline Manga & $23(88)$ & $0(00)$ & $3(12)$ & 26 & 0.27 & 0.44 & 0.20 \\
\hline Total & $119(86)$ & $3(2)$ & $16(12)$ & 138 & 0.31 & 0.46 & 0.21 \\
\hline Chi-square=9.197, p-value=0.1628, not significant at $\mathrm{p}<0.05$ \\
\hline
\end{tabular}

Source: Field Survey, 2016

\section{Climate change and sowing methods}

Environmental exploitations increased by human's leads to challenges to the global environmental change, which leads to rapid change on ecosystems in the world. With the changes in the environment system there is a need to change the planting methods also and adopt it according to the climate challenges. The respondents were asked about the sowing methods at the field for different crops. The data in these aspects are presented in Table 13, pointed that the majority of the respondents used broadcast methods as a sowing methods at the field followed by row to row methods of sowing and mechanized. The data pointed that the most commonly used methods by the respondents in the area were the broad casting methods, this may be due to the easiness of the methods for the sowing of crops.

Table 13. Distribution of respondent's on the basis of sowing methods

\begin{tabular}{|c|c|c|c|c|c|c|c|c|}
\hline \multicolumn{9}{|c|}{ Sowing methods } \\
\hline UCs Name & Broadcast & $\begin{array}{l}\text { Row to } \\
\text { row }\end{array}$ & Machines & Other & Total & Mean & $\begin{array}{l}\text { Std. } \\
\text { Dev. }\end{array}$ & Var. \\
\hline Garo shah & $35(58)$ & $15(25)$ & $4(7)$ & $6(10)$ & 60 & 0.28 & 0.45 & 0.20 \\
\hline Machai & $18(50)$ & $10(28)$ & $3(8)$ & $5(14)$ & 36 & 0.25 & 0.44 & 0.19 \\
\hline Shahbaz Gari & $38(52)$ & $24(33)$ & $4(6)$ & $6(9)$ & 72 & 0.29 & 0.45 & 0.20 \\
\hline Manga & $26(54)$ & $16(33)$ & $2(4)$ & $4(9)$ & 48 & 0.31 & 0.46 & 0.21 \\
\hline Total & $117(54)$ & $65(30)$ & $13(6)$ & $21(10)$ & $216^{*}$ & 0.28 & 0.45 & 0.20 \\
\hline
\end{tabular}

$*$ The total exceed because of the multiple responses by the respondents

Source: Field Survey, 2016

Climate change and fertilizer use

Community and individual have to deal with different weather extremes like flood, storms and drought, for smallholder farmers autonomous adaptations are useful, which includes changing the rate of application of fertilizer and other different inputs [53]. The data in Table 14 presents the perceptions of 
the respondents regarding the methods used for the application of fertilizer. It is evident from the data that majority of the respondents used the broad cost and split methods for the application of fertilizer at the field in the area.

Table 14. Distribution of respondents on methods of fertilizer use

\begin{tabular}{|l|c|c|c|c|c|c|c|}
\hline \multicolumn{7}{|c|}{ Fertilizer use methods } \\
\hline UCs Name & Broadcast & Split & Other & Total & Mean & Std. Dev. & Var. \\
\hline Garo shah & $26(67)$ & $10(26)$ & $3(8)$ & 39 & 0.27 & 0.44 & 0.20 \\
\hline Machai & $10(48)$ & $7(33)$ & $4(19)$ & 21 & 0.33 & 0.47 & 0.22 \\
\hline Shahbaz Gari & $46(88)$ & $6(12)$ & $0(0)$ & 52 & 0.03 & 0.18 & 0.03 \\
\hline Manga & $22(85)$ & $4(15)$ & $0(0)$ & 26 & 0.05 & 0.23 & 0.05 \\
\hline Total & $104(75)$ & $27(20)$ & $7(5)$ & 138 & 0.17 & 0.33 & 0.12 \\
\hline \multicolumn{7}{|c|}{ Chi-square $=21.3004$, p-value $=0.00162$, significant at $\mathrm{p}<0.05$} \\
\hline
\end{tabular}

Source: Field Survey, 2016

\section{Climate change and water management/ irrigation sources}

In area where there is excess rainfall, preventing logging and leaching of nutrient by erosion, using weather forecast information to reduce the risk of climate events different water management practices i.e. improving water-holding capacity of the soil, making physical soil and water conservation structures, collecting water to conserve moisture of the soil, and changing the amount and timing of irrigation [53]. Best water management practices improve the soil quality and made it sustainable. The data in Table 15, presents the water management practices of the respondents in the area. The data shows that most of the respondents use the canal and tube well as an irrigation sources in the area followed by the rain water. This tells that the area having government canal system and where this system is not available then the tube well was used as a source of irrigation. Among the union councils, there was less variation in the opinion of the respondents about the irrigation water sources.

Table 15. Distribution of respondents on water management/ irrigation sources

\begin{tabular}{|l|c|c|c|c|c|c|c|c|}
\hline \multicolumn{1}{|c|}{ Water management practices } \\
\hline UCs Name & Canal & Tube well & Rain & Other & Total & Mean & Std. Dev. & Var. \\
\hline Garo shah & $36(52)$ & $22(32)$ & $6(9)$ & $5(7)$ & 69 & 0.44 & 0.49 & 0.25 \\
\hline Machai & $16(46)$ & $12(34)$ & $7(20)$ & $0(0)$ & 35 & 0.46 & 0.50 & 0.25 \\
\hline Shahbaz Gari & $42(52)$ & $25(31)$ & $14(17)$ & $0(0)$ & 81 & 0.41 & 0.49 & 0.24 \\
\hline Manga & $26(55)$ & $14(30)$ & $7(15)$ & $0(0)$ & 47 & 0.39 & 0.49 & 0.24 \\
\hline Total & $120(52)$ & $73(31)$ & $34(15)$ & $5(2)$ & $232 *$ & 0.42 & 0.50 & 0.25 \\
\hline
\end{tabular}

$*$ The total exceed because of the multiple responses by the respondents

Source: Field Survey, 2016

\section{Main constraints to crop production}

Understanding the socio-economic, operational barriers and biophysical challenges to the climate change process are important as this will help the policy makers and the farmers to overcome the climate change phenomena sustainably. The data in
Table 16 present the perceptions of the respondents regarding the main constraints to the crop production. The data shows that the main constraints to the crop production was the timely unavailability of different chemicals, lack of implement and capital, crop damage by floods due to climate 
change, inadequate rain fall and unavailability of seed and fertilizer. Many factors are responsible for these constraints, including poverty, illiteracy, lack of interest and unawareness.

Table 16. Distribution of respondents on constraints to crop production

\begin{tabular}{|c|c|c|c|c|c|c|c|}
\hline \multicolumn{8}{|c|}{ Constraints to crop production } \\
\hline UCs Name & $\begin{array}{l}\text { Unavailability } \\
\text { of pesticide }\end{array}$ & $\begin{array}{l}\text { Lack of } \\
\text { capital }\end{array}$ & $\begin{array}{l}\text { Lack of } \\
\text { main } \\
\text { implement }\end{array}$ & $\begin{array}{l}\text { Crop damaged } \\
\text { due to } \\
\text { floods/weather }\end{array}$ & $\begin{array}{l}\text { Inadequate } \\
\text { rainfall }\end{array}$ & $\begin{array}{l}\text { Unavailability } \\
\text { of seed and } \\
\text { fertilizer }\end{array}$ & Total \\
\hline Garo shah & $31(26)$ & $11(9)$ & $19(16)$ & $19(16)$ & $24(21)$ & $13(11)$ & 117 \\
\hline Machai & $13(21)$ & $6(10)$ & $10(16)$ & $18(28)$ & $7(11)$ & $9(14)$ & 63 \\
\hline Shahbaz Gari & $40(23)$ & $34(19)$ & $41(23)$ & $40(23)$ & $8(5)$ & $12(7)$ & 175 \\
\hline Manga & $24(23)$ & $22(21)$ & $23(22)$ & $18(17)$ & $12(11)$ & $7(7)$ & 106 \\
\hline Total & $108(23)$ & $73(16)$ & $93(20)$ & $95(21)$ & $51(11)$ & $41(9)$ & $461^{*}$ \\
\hline
\end{tabular}

* The total exceed because of the multiple responses

Source: Field Survey, 2016

Climate change mitigation and adaptation strategies

Mitigative and adaptive management involves simultaneous implementation of adaptation measures and policies in different localities, comparing and evaluating the result to test hypothesis about the behavior of complex systems of the climate changes according to the needs of the local situation.
The data in Table 17 shows the respondents perception about the adaptive and mitigative measure adopted by the farmers to overcome the phenomena of climate change. The main adaptive and mitigative measure of the farmers were changes in planting time, best choice of crop, best choice of seeds changes in weeding dates and frequency, changes in fertilizer application and timing.

Table 17. Distribution of respondents on adaptive and mitigative measures

\begin{tabular}{|l|l|l|l|l|l|l|}
\hline UCs Name & $\begin{array}{l}\text { Change in } \\
\text { planting } \\
\text { time }\end{array}$ & $\begin{array}{l}\text { Best } \\
\text { choice of } \\
\text { crop }\end{array}$ & $\begin{array}{l}\text { Best } \\
\text { choice of } \\
\text { seed }\end{array}$ & $\begin{array}{l}\text { Change in } \\
\text { weeding dates } \\
\text { and frequency }\end{array}$ & $\begin{array}{l}\text { Change in } \\
\text { fertilizer } \\
\text { application }\end{array}$ & Total \\
\hline Garo shah & $5(8)$ & $28(44)$ & $26(41)$ & $4(6)$ & $1(1)$ & 64 \\
\hline Machai & $7(22)$ & $11(34)$ & $10(31)$ & $1(1)$ & $3(9)$ & 32 \\
\hline Shahbaz Gari & $20(34)$ & $23(40)$ & $11(19)$ & $3(5)$ & $1(2)$ & 58 \\
\hline Manga & $8(20)$ & $16(40)$ & $11(28)$ & $2(5)$ & $3(7)$ & 40 \\
\hline Total & 40 & 78 & 58 & 10 & 8 & $194^{*}$ \\
\hline \multicolumn{7}{|c|}{ Chi-square $=21.363, p$-value $=0.0453$, significant at $\mathrm{p}<0.05$} \\
\hline
\end{tabular}

* The total exceed because of the multiple responses Source: Field Survey, 2016

\section{Effect of rising temperature on crops and livestock}

Climate change is a dynamic process disturbing worldwide air/ocean temperature and these long and short term episodes of heat stress are predicted to occur more frequently as a result of global warming, affecting crop yield and decreasing crop quality [54]. The data in this regards presented in Table 18, shows the respondent's perception regarding the effect rising temperature on crop and over all livelihood level. Majority of the respondents agreed that due to raising temperature the crop yield was decreased and also affected the quality of crops. 
Climate changes have comprehensive cost for livestock production, mainly arising from its impact on grassland and rangeland productivity i.e. warmer temperatures and rainfall patterns produce a greater impact of rangeland biodiversity which influence livestock production and it is indisputable that grass, legumes and shrub composition in rangeland constitute the important determinant of livestock productivity [55]. The farmers perceptions in this regards are presented in Table 19 (values in parenthesis in all tables are the percentages), pointed that due to climate changes the production of livestock was decreased in the area and also the number are decreased as many diseases attacking the animals in the area.

Table 18. Distribution of respondents on rising temperature effect on agriculture

\begin{tabular}{|l|c|c|c|c|c|c|c|c|}
\hline \multicolumn{1}{|c|}{ Effect of rising temperature } \\
\hline UCs Name & Low income & Low yield & $\begin{array}{l}\text { Effect } \\
\text { quality }\end{array}$ & Other & Total & Mean & $\begin{array}{l}\text { Std. } \\
\text { Dev. }\end{array}$ & Var. \\
\hline Garo shah & $0(0)$ & $22(56)$ & $15(38)$ & $2(6)$ & 39 & 0.23 & 0.42 & 0.17 \\
\hline Machai & $1(5)$ & $11(52)$ & $07(33)$ & $2(10)$ & 21 & 0.23 & 0.42 & 0.18 \\
\hline Shahbaz Gari & $0(0)$ & $38(73)$ & $13(25)$ & $01(2)$ & 52 & 0.21 & 0.40 & 0.16 \\
\hline Manga & $0(0)$ & $18(69)$ & $07(27)$ & $01(4)$ & 26 & 0.18 & 0.39 & 0.15 \\
\hline Total & $1(1)$ & $89(65)$ & $42(30)$ & $06(4)$ & 138 & 0.21 & 0.41 & 0.17 \\
\hline \multicolumn{10}{|c|}{ Chi-square $=10.689$, p-value $=0.298$, not significant at $\mathrm{p}<0.05$} \\
\hline
\end{tabular}

Source: Field Survey, 2016

Table 19. Distribution of respondents on rising temperature effect on livestock Effect of increased temperature on livestock about availability of grasses/fodder

\begin{tabular}{|l|c|l|l|l|c|c|c|c|}
\hline UCs Name & Low yield & $\begin{array}{l}\text { Effects } \\
\text { livestock } \\
\text { number }\end{array}$ & $\begin{array}{l}\text { Other } \\
\text { factors }\end{array}$ & $\begin{array}{l}\text { Don't } \\
\text { know }\end{array}$ & Total & Mean & $\begin{array}{l}\text { Std. } \\
\text { Dev. }\end{array}$ & Var. \\
\hline Garo shah & $10(27)$ & $23(51)$ & $0(00)$ & $6(16)$ & 39 & 0.23 & 0.42 & 0.18 \\
\hline Machai & $4(21)$ & $07(26)$ & $2(11)$ & $8(42)$ & 21 & 0.25 & 0.43 & 0.19 \\
\hline Shahbaz Gari & $16(53)$ & $21(16)$ & $4(8)$ & $11(22)$ & 52 & 0.24 & 0.43 & 0.18 \\
\hline Manga & $09(39)$ & $3(11)$ & $3(11)$ & $11(39)$ & 26 & 0.48 & 1.50 & 2.26 \\
\hline Total & $39(28)$ & $54(39)$ & $09(7)$ & $36(26)$ & 138 & 0.30 & 0.70 & 0.70 \\
\hline \multicolumn{7}{|c|}{ Chi-square $=20.324, p$-value $=0.0160$, significant at $p<0.05$} \\
\hline
\end{tabular}

\section{Source: Field Survey, 2016}

\section{Conclusion}

Main findings of this study conclude that majority of the respondents having the knowledge of climate change and experience it and due to it the monsoon timing are increased from the normal and also some people reported for less rain during the crop growing seasons due to climate change. The reasons for this was the over population and deforestation. Climate change effect the production and cultivation of crops and livestock. Climate change adversely affected all aspects of the farmers in the area and brought the shifting/diversification from one profession to the others. Conventional, zero and hand digging tillage system were used in the area for the operation of the field land. Main constraints to the crop production was the timely unavailability of different chemicals, lack of implement and capital, crop damage by floods due to climate change, inadequate rain fall and unavailability of seed and fertilizer. The main adaptive and mitigative 
measure of the farmers were changes in planting time, best choice of crop/seed changes in weeding dates/frequency and changes in fertilizer application and timing.

\section{Authors' contributions}

Study was designed: M Israr, Field survey conducted: MU Rehman, Data analyzed by: M Israr, Wrote the paper: S Ahmad.

\section{Acknowledgements}

This is to acknowledge the support of all the selected respondents who willingly provided all the necessary information for this research study. As well, we extend our cordial thanks to those experts who took time to review and comment on this research work for its improvement.

\section{References}

1. Parihar CM, Jat SL, Singh AK, Kumar B, Pradhan S, Pooniya V, Dhauja A, Chaudhary V, Jat M L, Jat RK \& Yadav OP (2016). Conservation agriculture in irrigated intensive maize-based systems of north-western India: effects on crop yields, water productivity and economic profitability. Field Crop Res 193, 104116.

2. LI RL \& Geng S (2013). Impacts of climate change on agriculture and adaptive strategies in China. J Integr Agr, 12, 1402-1408.

3. Metzger MJ, Rounsevell MDA, AcostaMichlik L, Leemans R \& Schroter D (2006). The vulnerability of ecosystem services to land use change. Agric Ecosyst Environ 114: 69-85.

4. Houet T, Loveland TR, Hubert-Moy L, Gaucherel C, Napton D, Barnes CA \& Sayler K (2010). Exploring subtle land use and land cover changes: a framework for future landscape studies. Landsc Ecol, 25(2): 249-266.

5. Chaudhary P \& Bawa KS (2011). Local perceptions of climate change validated by scientific evidence in the Himalayas. Biol. Lett. 7: 767-770.

6. Falco SD, Yesuf M, Kohlin G \& Ringler
C (2011). Estimating the Impact of Climate Change on Agriculture in LowIncome Countries: Household Level Evidence from the Nile Basin, Ethiopia. Environ Resour Econ 52(4), 457-478.

7. Intergovernmental Panel on Climate Change (IPCC) (2014). Climate Change 2014-Impacts, Adaptation and Vulnerability: Regional Aspects. Cambridge University Press.

8. YE LM, Malingreau JP, Tang HJ \& Van Ranst E (2016). The breakfast imperative: The changing context of global food security. J Integr Agr, 15: 1179-1185.

9. Burke M, Hsiang SM \& Miguel E (2015). Global non-linear effect of temperature on economic production. Nature 527: 235-239.

10. Zhao J, Yang X, Lv S, Liu Z \& Wang J (2014). Variability of available climate resources and disaster risks for different maturity types of spring maize in Northeast China. China. Reg. Environ. Chang. 14: 17-26.

11. Weber EU (2010). What shapes perceptions of climate change? WIREs Climate Change, 1: 332-342.

12. Israr M, Awan N, Jan D, Ahmad N \& Ahmad S (2016). Patients' Perception, Views and Satisfaction with Community Health Center Services at Mardan District of Khyber Pakhtunkhwa. Am J Public Health Res 4(3): 79-87.

13. Connor DJ, van-Rees H \& Carberry PS (2015). Impact of systems modelling on agronomic research and adoption of new practices in smallholder agriculture. $J$ Integr Agr, 14(8): 1478-1489.

14. Menapace L, Colson G \& Raffaelli R (2015). Climate change beliefs and perceptions of agricultural risks: an application of the exchangeability method. Glob Environ Chang 35: 70-81.

15. Wang JX, Huang JK \& Jun YANG (2014). Overview of impacts of climate change and adaptation in China's 
agriculture. J Integr Agr 13: 1-17.

16. Bryan E, Deressa TT, Gbetibouo GA \& Ringler C 2009. Adaptation to climate change in Ethiopia and South Africa: options and constraints. Environ Sci Policy 12(4): 413-426.

17. Saxena KG \& Rao KS (2009). Climate change, biodiversity and livelihoods in Indian Himalaya: the elements of uncertainty and diverse perceptions. In Proceeding of national seminar on climate change: data requirements and availability, institute for social and economic change, Bangalore and ministry of statistics and programme implementation, Government of India publication pp. 78-88.

18. Israr M, Faraz M, Jan D, Ahmad N \& Ahmad S (2016). Farming Community Perceptions about Climate Change in Khyber Pakhtunkhwa Pakistan. World J Agric Res 4(3): 70-76.

19. Esham M \& Garforth C (2013). Agricultural adaptation to climate change: insights from a farming community in Sri Lanka. Mitigation Adapt. Strateg. Glob Chang 18(5): 535549.

20. Carleton TA \& Hsiang SM (2016). Social and economic impacts of climate. Science 353.

21. Dell M, Jones BF \& Olken BA (2014). What do we learn from the weather? The new climate economy literature. $J$ Econ Lit 52(3): 740-798.

22. Berrang-Ford L, Ford JD, Lesnikowski A, Poutiainen C, Barrera M \& Heymann SJ (2014). What drives national adaptation? A global assessment. Clim. Change, 124 (1-2): 441-450.

23. Dannevig H \& Hovelsrud GK (2015). Understanding the need for adaptation in a natural resource dependent community in Northern Norway: issue salience, knowledge and values. Clim Change 135(2): 261-275.
24. Parry ML, Canziani OF, Palutikof JP, van-der LPJ \& Hanson CE (2007). IPCC, 2007: climate change 2007: impacts, adaptation and vulnerability. Contribution of working group II to the fourth assessment report of the intergovernmental panel on climate change.

25. Costinot A, Donaldson D \& Smith C (2016). Evolving comparative advantage and the impact of climate change in agricultural markets: Evidence from 1.7 million fields around the world. J Polit Econ 124(1): 205-248.

26. Pradhan NS (2012). Role of Policy and Institutions in Local Adaptation to Climate Change Case studies on responses to too much and too little water in the Hindu Kush Himalayas.

27. Di-Falco S, Veronesi $M$ \& Yesuf $M$ (2011). Does adaptation to climate change provide food security? A microperspective from Ethiopia. Am J Agric Econ 93(3): 825-842.

28. Lobell DB, Hammer GL, McLean G, Messina C, Roberts MJ \& Schlenker W (2014). Reply to temperature and drought effects on maize yield. Nat. Clim. Change 4(4): 234-234.

29. Lobell DB \& Burke MB (2008). Why are agricultural impacts of climate change so uncertain? The importance of temperature relative to precipitation. Environ Res Lett 3(3):034007.

30. Thornton PK, Ericksen PJ, Herrero M \& Challinor AJ (2014). Climate variability and vulnerability to climate change: a review. Glob Chang Biol 20(11): 33133328.

31. Bindi M \& Olesen J (2011). The responses of agriculture in Europe to climate change. Reg Environ Chang 11 (1): 151-158.

32. Rosenzweig C, Elliott J, Deryng D, Ruane AC, Muller C, Arnett A, Boote KJ, Folberth C, Glotter M, Khabarov N 
\& Neumann K (2014). Assessing agricultural risks of climate change in the 21st century in a global gridded crop model intercomparison. Proc Natl Acad Sci 111(9): 3268-3273.

33. Tendall DM \& Gaillard G (2015). Environmental consequences of adaptation to climate change in Swiss agriculture: an analysis at farm level. Agric Syst 132: 40-51.

34. Webber H, Gaiser T \& Ewert F (2014). What role can crop models play in supporting climate change adaptation decisions to enhance food security in Sub-Saharan Africa? Agric Syst 127: 161-177.

35. Alary V, Corbeels M, Affholder F, Alvarez S, Soria A, Xavier JV, Da-Silva FAM \& Scopel E (2016). Economic assessment of conservation agriculture options in mixed crop-livestock systems in Brazil using farm modelling. Agric Syst 144: 33-45.

36. Rigolot C, Voil P, Douxchamps S, Prestwidge D, Van-Wijk M, Thornton P, Rodriguez D, Henderson B, Medina D \& Herrero M (2016). Interactions between intervention packages, climatic risk, climate change and food security in mixed crop livestock systems in Burkina Faso. Agr Syst 151: 217-224.

37. HE YB \& CAI WM (2016). Linking a farmer crop selection model (FCS) with an agronomic model (EPIC) to simulate cropping pattern in Northeast China. $J$ Integr Agr 15: 2417-2425.

38. Zinyengere N, Crespo O \& Hachigonta $S$ (2013). Crop response to climate change in southern Africa: a comprehensive review. Glob Planet Change 111: 118-126.

39. Hillier J, Walter C, Malin D, GarciaSuarez T, Mila-i-Canals L \& Smith P (2011). Afarm- focused calculator for emissions from crop and livestock production. Environ. Model Softw 26(9):
1070-1078.

40. Stukel D \& Deitchler M (2012). Addendum to FANTA sampling guide by Robert Magnani (1991): Correction to Section 3.3.1. Determining the number of households that need to be contacted. Washington, DC: FHI, 360.

41. Smit B, Burton I, Klein RJ \& Wandel J (2000). An anatomy of adaptation to climate change and variability. Clim Change 45(1): 223-251.

42. Slegers MF (2008). "If only it would rain": Farmers' perceptions of rainfall and drought in semi-arid central Tanzania. J. of Arid Env 72: 2106-2123.

43. Afzaal M, Haroon MA \& Zaman Q (2009). Interdecadal oscillations and the warming trend in the area-weighted annual mean temperature of Pakistan. Pak J Meteorol 6(11): 13-19.

44. Sheikh MM, Iqbal MM, Ali G \& Khan AM (2011). Global warming in the context of Pakistan: Major concerns and remedial strategies. Changing environmental pattern and its impact with special focus on Pakistan, 16.

45. Mendelsohn R, Dinar A \& Sanghi A (2001). The effect of development on the climate sensitivity of agriculture. Environ Dev Econ 6: 85-101.

46. Jiang L \& Hardee K (2009). How do recent population trends matter to climate change? Popul Res Policy Rev 30(2): 287-312. DOI: 10.1007/s11113010-9189-7.

47. Garrett KA, Forbes GA, Savary S, Skelsey P, Sparks AH, Valdivia C, Bruggen AHC, Willocquet L, Djurle A, Duveiller E, Eckersten H, Pande S, Vera C \& Yuen J (2011). Complexity in climate-change impacts: an analytical framework for effects mediated by plant disease. Plant Pathol 60: 15-30.

48. United States Department of Agriculture (USDA) (2013). Service S, Foster C, Hilliard P \& Ray T. 2006. United States 
Department of Agriculture, National Agricultural Statistics Service, Agricultural Statistics 2006, (866).

49. Rasul G, Chaudhry QZ, Mahmood A \& Hyder W (2011). Effect of temperature rise on crop growth and productivity. Pak J Meteorol 8: 53-62.

50. IFAD (2015). Annual Report 2015. Retrieved from www.ifad.org/documents/10180/a1b087 10-57c8-40fe-878d-c598a96f0d95.

51. Schmidt MWI, Torn MS, Abiven S, Dittmar T, Guggenberger G, Janssens IA, Kleber M, Kogel KI, Lehmann J, Manning DAC, Nannipieri P, Rasse DP, Weiner S \& Trumbore SE (2011). Persistence of soil organic matter as an ecosystem property. Nature Vol 478: pp. 49-56.

52. Ugalde D, Brungs A, Kaebernick M,
McGregor A \& Slattery B (2007). Implications of climate change for tillage practice in Australia. Soil and Tillage Res Vol. 97 pp. 318-330.

53. Amedie FA (2013). Impacts of Climate Change on Plant Growth, Ecosystem Services, Biodiversity, and Potential Adaptation Measure (Doctoral dissertation, MS thesis in Atmospheric Science, University of Gothenburg, Sweden).

54. Mohammed AR \& Tarpley L (2011). Effects of high night temperature on crop physiology and productivity: Plant growth regulators provide a management option. INTECH Open Access Publisher.

55. Assan N (2014). Gender disparities in livestock production and their implication for livestock productivity in Africa. J Anim Sci 3(5): 126-138. 